\title{
Consideration of Semarang District Court Judge's Decision in Case Dropped Because The Crime of Defense of Emergency
}

\author{
Zulfikar Hanafi Bahri ${ }^{1}$
}

Abstract. This study aims to determine the basic consideration of the judge and the factors that influence their consideration of the judge in the verdict against perpetrators of criminal acts because of a defense emergency, given the motivation offenders who commit criminal acts solely for self-defense, and the factors that influence consideration of the judge in the verdict against the accused, so it took the foresight of the judges who handle it and the basis and reasoning of judges itself in implementing its decision. In completing this study, the authors use a step to find data and collect data either through the study of literature and other data sources and to analyze the subject and object data obtained through empirical juridical approach, while sampling was conducted through interviews with directional type. Based on research by the author in the location, it can be authors conclude that consideration of the judge in the verdict against perpetrators of criminal because of a defense emergency in addition based on the provisions of the Act, namely Article 49 of the Code of Criminal Law, taking into account factors about the motives of the accused in criminal offense must be solely for self-defense, so that when the verdict, can be justified by fair in accordance with the legislation and of course also the aspect of sociological and psychological defendant, to obtain a ruling that can be justified legally, morally, and religion by the judge.

Keywords: Consideration; Justice; Defense; Emergency.

\section{Introduction}

Basically everyone is entitled to defend himself. Self-defense is the right of human beings, so that the defense argument forced the Criminal Code is seen as a justification. In the 1945 Constitution, in Article 28G (1) stated everyone is entitled to protection of self, family, honor, dignity, and property under his control, and has the right to feel secure and protection from threats to do or not to do something is human rights. $^{2}$

According to Simons as quoted Erdianto Effendi, a criminal act is an act or acts punishable by the law, contrary to the law and carried out by someone who is able to take responsibility. ${ }^{3}$

The word " offense " came from the Latin, namely delictum. In German called delict, in French called Delit, and in Dutch called delict. In the Dictionary of Indonesian

\footnotetext{
1 Lawyer Student Master Program (S2) of Law Faculty of Law Unissula Semarang email: zulfikarhanafi@ymail.com

${ }^{2}$ Frans Maramis 2012 Hukum Pidana Umum dan Tertulis Di Indonesia Jakarta: PT Raja Grafindo Persada p: 114

${ }^{3}$ Erdianto Effendi 2011 Hukum Pidana Indonesia-Suatu Pengantar Bandung: PT Refika Aditama.
} 
Language, meaning the offense is defined as follows: "The act punishable as a violation of the Act a criminal offense "14

In certain circumstances, the makers of criminal acts can do nothing which leads to the occurrence of a crime, even if actually did not want. So it is not in place when people still expect the person concerned to be on the path established by law. Criminal acts sometimes can not be avoided by the makers of a crime, because of something that comes from outside himself. Factors that come from outside himself that is causing maker criminal offense can not do otherwise result in mistakes being erased. In this connection the criminal liability still waiting until it is certain there is no reason that eliminate errors maker criminal offense. Although the author may be reproached, ${ }^{5}$

Case No. 1002 / Pid.B / 2008 / Pn. SMG on trial in Semarang District Court is a matter about which causes the group fights left casualties. At the trial, the judges acquitted the accused of all charges. Such decisions are essentially based on the differences in the statements of witnesses of the prosecution or the accused and his legal counsel that led to the judges, based on the conviction. Such decisions are based on the martial aspect of force (noodweer). And if you refer to the events in detail and consider witness testimony of both parties, it is possible that the judges are not acquitted the defendant. ${ }^{6}$

Based on the background research that has been described above, the researchers focused into a title "Consideration Of Semarang District Court Judge's Decision In Case Dropped Because The Crime Of Defense Of Emergency".

Based on the description of the background of the above, it can be the problem as follows: Factors that influence consideration of the judge in the criminal case verdict for the defense emergency (Noodweer) in Semarang District Court?

\section{Research Methods}

This study juridical empirical approach, which is a method used to solve the problem by first examining the existing secondary data and then proceed with research on primary data in the field ${ }^{7}$, associated with Judge judgment in the criminal case verdict due to an emergency plea in Semarang district court.

This type of research is descriptive analysis, namely with the gathering of data related Judge judgment in the criminal case verdict due to an emergency plea in court Semarang, Then the data in the mentioned and analyzed by positive law and legal theory exists.

Sources of data in this research is based on primary and secondary data. Primary data is data obtained directly from the location of the research / study subjects. ${ }^{8}$ This research was conducted in Semarang District Court, to determine directly and analyze Judge judgment in the criminal case verdict due to an emergency plea in Semarang

\footnotetext{
4Leden Marpaung 2012 Asas-Teori-Praktik Hukum Pidana Jakarta: Sinar Grafika p: 7

${ }^{5}$ Mahrus Ali 2012 Dasar-Dasar Hukum Pidana Jakarta: Sinar Grafika p: 180-181

6 Nur yadi 13 Jan 2014 "Analisis Putusan No 1002/Pid.B/2008/PN.SMG tentang Perkelahian Kelompok" http://eprints.walisongo.ac.id/1306/ accessed on March 132014

${ }^{7}$ Soerjono Soekanto 1984 Pengantar Penelitian Hukum cetakan ketiga Jakarta : UI Press p 52

${ }^{8}$ Ibid p 51
} 
district court. In accordance with the issues to be discussed, the subject of this study is the Semarang District Court judges who handle criminal cases as a defense emergency (Noodweer).

While the secondary data, ie data obtained from the research literature in the form of legal materials. ${ }^{9}$ Legal materials consist of: Material primary law: that legislation or legal material related to the object of the research that will be studied are: the Criminal Code (the Code Penal), Code of Criminal Procedure (the Code of Criminal Procedure ), Act No. 48 of 2009 concerning the judicial authorities., other legislation relating to the material of writing,

Secondary law: the legal materials that provide further explanation of the primary legal materials, namely: books literature and may provide an explanation about the primary legal materials and writings Various laws related to the issue to be studied.

Tertiary legal materials: the legal materials that provide instructions and explanations of the law and secondary law, which consists of Law Dictionary, Dictionary Indonesian Dictionary of English

In this study way to collect primary data is to conduct the interview, the interview was based on a list of questions in advance. Interviews were conducted with the type of directional (directive interview), that is an interview by using a list of questions that had been prepared beforehand. ${ }^{10}$

The data have been submitted subsequent studies were analyzed descriptively qualitative.

\section{Results And Discussion}

\subsection{Factors Affecting Decision Consideration Judge In Case Dropped Due Crime Emergency Defense Semarang District Court}

195 provisions of the Criminal Procedure Code, which reads: " all court decision is only valid and have the force of law if uttered in the hearing open to the public ". Noting the provisions of Article 195 Criminal Procedure sound can be picked understanding ${ }^{11}$ :

- Legitimacy of the decision and that decision has the force of law, trial courts should be pronounced " open to the public ".

- All decisions without exception should be pronounced in a session open to the public.

Author interviews on the Semarang District Court Judge, Billy Susanto., SH, MH on Tuesday, May 13, 2014 at 9:00 a.m. to 9:50, explains that there are several factors that influence the decision of a judge in a criminal case as an emergency defense, among others:

- Legal factors

Seeing the above problems, the provisions of the law against criminals as a defense emergency has been regulated in the Act, so as to drop the verdict can refer to the

\footnotetext{
${ }^{9}$ Soerjono Soekanto dan Sri Mammudji 1990 Penelitian Hukum Normatif Pengantar Singkat Jakarta : Rajawali Press $\mathrm{p} 14$

${ }^{10}$ Maria S.W 1997 Pedoman Pembuatan Usulan Penelitian Jakarta : PT Gramedia Pustaka Utama p 60

${ }^{11}$ Yahya Harahap 2012 Pembahasan Permasalahan dan Penerapan.KUHAP Jakarta: Sinar Grafika p: 378
} 
Act to see his case as well as the legal relations that include evidence, witnesses, and the process the occurrence of the case and legal facts in the trial. In this case the judge saw that to make a decision against the offender as an emergency defense can be guided by the Act or see jurisprudence in the same case.

- Actor factor

These factors also contribute to affect consideration of the judge in the verdict against perpetrators of criminal acts because of a defense emergency, by looking at the intention of the perpetrators themselves that there is no intention against the law, in the sense that the position of the real perpetrators is as the party had suffered a life-threatening, and because there are no other measures for the perpetrators to escape, so the motive of the perpetrator of a criminal act is due solely to defend themselves, either for themselves or others from attacks that come suddenly, or it can also be said of the perpetrators in state of mental shock so spontaneously to defend against an attack that threatens the safety of self, others and property.

- Judge factor

Given the position as a judge is not easy, a lot of things to be considered before a verdict free from any legal action against the perpetrators of criminal acts because of a defense emergency, the judges handling the criminal case as a defense emergency is expected to professional in their duties, so that the decision produced can also be justified by the law. As enforcers of justice, it should be a judge prioritize the essentials of justice, so that every decision that is produced is absolutely appropriate to satisfy the sense of justice, legal certainty and benefit the community.

\section{Closing}

\subsection{Conclusion}

Based on a description of the problem, the authors conclude as follows;

- Factors that influence the consideration of the judge in the verdict against the perpetrators of criminal acts because of a defense emergency, among other things:

- Factors Law: namely the implementation of article relied upon consideration of the judge in the verdict against perpetrators of criminal acts because of a defense emergency, the judge may be guided by the provisions of the legislation that has been regulated by the government to look at the legal relations that occur as a reinforcement of a decision, or can reflect on the jurisprudence in the same case.

- Factors actors: that is the object of the criminal case as an emergency defense took part in influencing the judge's decision. In this case to note is; the intention of the perpetrator himself that there was no intent against the law, in the sense that the position of the actual perpetrator is a party that got life-threatening attacks, and because there is no other effort for the offender to escape, so the motive of the perpetrator of a criminal act is because only to defend themselves, either for themselves or others from attacks that come suddenly, or it can also 
be said of the perpetrators in a state of mental shock so spontaneously to defend against an attack that threatens the safety of self, others, or property object.

- Factor judge: that in the trial of criminal case for emergency defense, Given the position as a judge is not easy, a lot of things to be considered before a verdict free from any legal action against the perpetrators of criminal acts because of a defense emergency, the judges handling the criminal case as a defense emergency is expected to professional in their duties, so that the decision produced can also be justified by the law. Any decision of the judge is also expected to reflect a sense of justice as in accordance with the specifics and the task of a judge is God's representative on earth.

\subsection{Suggestion}

From the description of these problems there are a few things recommend:

- The security forces (especially the National Police) wanted her to upgrade security in society and security actors always be expected to respond swiftly to protect public safety, so as to prevent the occurrence of a crime, considering many cases of law violations that occurred in the life of society. As with the case of theft, rape and murder, which is a very dangerous act for the salvation of the human body and soul, and can threaten the security and welfare of the community.

- Judge in providing rehabilitation or 'recoverable defendant rights in the ability to position and dignity as well as his dignity, his going to pay attention to several things; the vindication of the accused, and the compensation process is materially given during the process of arrest until the trial is finished, a lot of interest and the defendant were harmed during the process the defendant can not work to support themselves and their families.

\section{Bibliography}

[1] Erdianto Effendi 2011 Hukum Pidana Indonesia-Suatu Pengantar Bandung: PT Refika Aditama.

[2] Frans Maramis 2012. Hukum Pidana Umum dan Tertulis Di Indonesia Jakarta: PT Raja Grafindo Persada.

[3] Hajar M 2017 model-model Pendekatan dalam penelitian Hukum dan Fiqh Sleman : Kalimedia,

[4] Leden Marpaung 2012 Asas-Teori-Praktik Hukum Pidana Jakarta: Sinar Grafika.

[5] Maria S.W 1997 Pedoman Pembuatan Usulan Penelitian Jakarta : PT Gramedia Pustaka Utama.

[6] Mahrus Ali 2012. Dasar-Dasar Hukum Pidana Jakarta: Sinar Grafika.

[7] Abdulkadir Muhammad 2004 Hukum dan Penelitian Hukum Bandung : Citra Aditya Bakti.

[8] Soerjono Soekanto dan Sri Mammudji 1990 Penelitian Hukum Normatif Pengantar Singkat Jakarta : Rajawali Press.

[9] 1984 Pengantar Penelitian Hukum cetakan ketiga Jakarta : UI Press 
Jurnal Daulat Hukum Volume 1. No. 2 June 2018 : 495 - 500

[10] Yahya Harahap 2012 Pembahasan Permasalahan dan Penerapan.KUHAP Jakarta: Sinar Grafika.

[11] Nur yadi 13 Jan 2014 "Analisis Putusan No 1002/Pid.B/2008/PN.SMG tentang Perkelahian Kelompok" http://eprints.walisongo.ac.id/1306/ accessed on March 132014 